Article

\title{
High pH Stress Affects Root Morphology and Nutritional Status of Hydroponically Grown Rhododendron (Rhododendron spp.)
}

\author{
Ashley J. Turner (D), Camila I. Arzola and Gerardo H. Nunez *(D) \\ Horticultural Sciences Department, University of Florida, Gainesville, FL 32611, USA; \\ ashleyturner@ufl.edu (A.J.T.); carzola@ufl.edu (C.I.A.) \\ * Correspondence: g.nunez@ufl.edu
}

Received: 25 June 2020; Accepted: 9 August 2020; Published: 12 August 2020

check for updates

\begin{abstract}
Rhododendrons (Rhododendron spp.) are ornamental plants in the family Ericaceae that thrive in acidic soils and are challenged by neutral or alkaline soils. This soil requirement limits the locations where rhododendrons can be grown and causes chlorosis, diminished growth, and low survival when rhododendrons are grown in high $\mathrm{pH}$ soils. While growth and survival impacts are widely documented, little is known about how high pH soils cause these symptoms in rhododendrons. We hypothesized that high $\mathrm{pH}$ stress impacts root form and function, leading to nutrient deficiencies that limit plant growth. We tested this hypothesis in a hydroponic experiment. "Mardi Gras" rhododendron liners were grown in a complete nutrient solution at pH 5.5 (optimum pH) or pH 6.5 (high $\mathrm{pH}$ ) for 49 days. Biomass accumulation, nutrient uptake and concentration, and root stress were assessed. High $\mathrm{pH}$ nutrient solutions diminished leaf and root growth. Plants grown in high $\mathrm{pH}$ nutrient solutions developed clusters of short, highly branched roots. Plants grown in optimum $\mathrm{pH}$ did not exhibit this morphology. High $\mathrm{pH}$ affected the uptake and translocation of most essential nutrients. S and Mn deficiencies likely limited plant growth. High $\mathrm{pH}$ had a nuanced effect on root oxidative status. These results suggest that rhododendron root morphology and nutrient uptake are directly affected by high $\mathrm{pH}$ and that aboveground symptoms might be a consequence of impaired root function.
\end{abstract}

Keywords: ericaceae; calcifuge; cluster roots

\section{Introduction}

Rhododendrons (Rhododendron spp.) are ornamental plants in the family Ericaceae. While some taxa exhibit wide $\mathrm{pH}$ tolerance [1], most rhododendrons thrive in acidic soils ( $\mathrm{pH} 5.0$ to $\mathrm{pH}$ 6.0) and are challenged by neutral or alkaline soils [2]. Acidic soils are uncommon in gardens and landscapes, which limits the locations where rhododendrons can be planted [3].

Cultivation in high $\mathrm{pH}$ soils elicits several responses in rhododendron and other calcifuge plants. The most common stress symptom is mild to severe chlorosis. Chlorosis has been previously used as a tool to assess plant stress and select genotypes with high $\mathrm{pH}$ tolerance [3-5]. While chlorosis has been commonly ascribed to Fe deficiency, Fe concentration and Fe content were not measured in these studies. Additionally, research with other calcifuge plants suggests other nutrients might be involved. In blueberry (Vaccinium spp. section cyanococcus), chlorosis has been observed in plants grown in high $\mathrm{pH}$ soils, even though leaf Fe concentrations were not affected [6,7]. In cranberry (Vaccinium macrocarpon), shoot Fe, Mn, and Zn were lower in response to high pH nutrient solutions [8]. Further research is necessary to identify the cause and relevance of rhododendron chlorosis in high $\mathrm{pH}$ soils. 
Another common symptom of high $\mathrm{pH}$ stress is diminished growth. Rhododendrons grow less $[2,3]$ and have higher mortality rates $[5,9]$ in high $\mathrm{pH}$ soils than in acidic soils. Similar responses have been observed in blueberry, cranberry [8], heath (Erica spp.), and heather (Calluna vulgaris) [10].

Weak, chlorotic growth diminishes the value of ornamental and edible ericaceous plants. Research with other calcifuge plants suggests that root system morphology and physiology might be the link between nutritional deficiencies, impaired growth, and low survival. High $\mathrm{pH}$ soils reduce root growth in blueberry $[6,8]$ and cranberry [8]. Smaller root systems have limited access to water and nutrients in the soil [11], leading to other downstream symptoms. Size-independent responses have also been observed. Blueberry roots upregulate Fe uptake [12] and cranberry roots reduce their organic acid concentrations [13] and increase branching [14] in high $\mathrm{pH}$ soils or nutrient solutions. It is unknown whether size-dependent or -independent root responses are involved in the rhododendron response to high $\mathrm{pH}$.

This research aims to describe how high $\mathrm{pH}$ nutrient solutions affect rhododendrons. We hypothesized that high $\mathrm{pH}$ stress impacts root form and function, leading to nutrient deficiencies that limit plant growth. We tested this hypothesis in a hydroponic experiment.

\section{Results}

\subsection{Growth, Dry Weight, and Chlorosis}

"Mardi Gras" rhododendron liners were acclimated to a hydroponic growth system for 22 days. At the end of acclimation, plants weighed $38.14 \pm 2.53 \mathrm{~g}$ (mean \pm standard error). Subsequently, plants were transferred to optimum ( $\mathrm{pH}$ 5.5) or high $\mathrm{pH}(\mathrm{pH}$ 6.5) nutrient solutions. All plants grew during the 49-day treatment period, but plants in $\mathrm{pH} 5.5$ exhibited higher relative growth rates than plants in pH $6.5(0.40$ vs. $0.17, p=0.024)$. At the end of the experiment, plants grown in optimum $\mathrm{pH}$ solutions were larger than plants grown in high $\mathrm{pH}$ solutions (Table 1). Roots and leaves were the most affected organs. Stems were not affected, and plants did not bloom during the experiment. Plants grown in $\mathrm{pH} 5.5$ had larger root systems than plants grown in $\mathrm{pH}$ 6.5, but root to shoot ratios were not different between the treatments. Plants grown in optimal $\mathrm{pH}$ solutions did not exhibit root morphological changes during the experiment. In contrast, plants grown in high $\mathrm{pH}$ solutions developed short, highly-branched first and second order roots clustered together in the basal areas of higher-order roots (Figure 1). Plants grown in $\mathrm{pH} 5.5$ had larger total leaf area and leaf dry weight than plants grown in $\mathrm{pH}$ 6.5. Chlorosis was not detected visually or through transmittance (SPAD average $=27.21, p=0.950$ ) or image analysis-based methods (Dark Green Color Index average $=0.48$, $p=0.950)$ in either treatment.

Table 1. Biomass accumulation of "Mardi Gras" rhododendron grown in nutrient solutions with optimum ( $\mathrm{pH}$ 5.5) or high $\mathrm{pH}$ ( $\mathrm{pH}$ 6.5) for 49 days. Data reported are means \pm standard errors.

\begin{tabular}{ccccccc}
\hline $\begin{array}{c}\text { Nutrient } \\
\text { Solution pH }\end{array}$ & $\begin{array}{c}\text { Root Dry } \\
\text { Weight (g) }\end{array}$ & $\begin{array}{c}\text { Stem Dry } \\
\text { Weight } \mathbf{( g )}\end{array}$ & $\begin{array}{c}\text { Leaf Dry } \\
\text { Weight (g) }\end{array}$ & $\begin{array}{c}\text { Total Dry } \\
\text { Weight }(\mathbf{g})\end{array}$ & $\begin{array}{c}\text { Root to } \\
\text { Shoot Ratio }\end{array}$ & $\begin{array}{c}\text { Total Leaf } \\
\text { Area }\left(\mathbf{c m}^{\mathbf{2}}\right)\end{array}$ \\
\hline 5.5 & $10.50 \pm 0.64$ & $4.19 \pm 0.46$ & $4.88 \pm 0.35$ & $20.38 \pm 1.35$ & $1.15 \pm 0.04$ & $557.77 \pm 33.56$ \\
6.5 & $8.05 \pm 0.54$ & $4.07 \pm 0.45$ & $3.35 \pm 1.69$ & $15.93 \pm 1.51$ & $1.09 \pm 0.09$ & $412.31 \pm 18.75$ \\
$p$-value $^{1}$ & 0.009 & 0.857 & 0.042 & 0.049 & 0.649 & $<0.001$ \\
\hline
\end{tabular}

${ }^{1}$ Data were analyzed through one-way analysis of variance. 


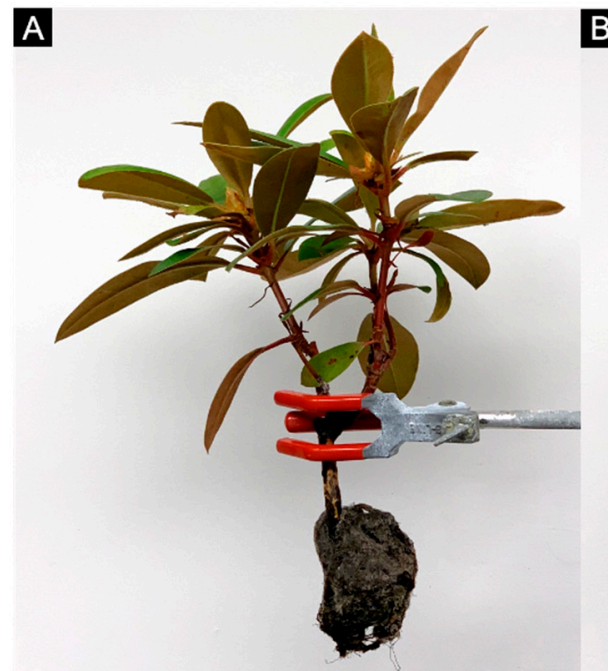

\section{B}

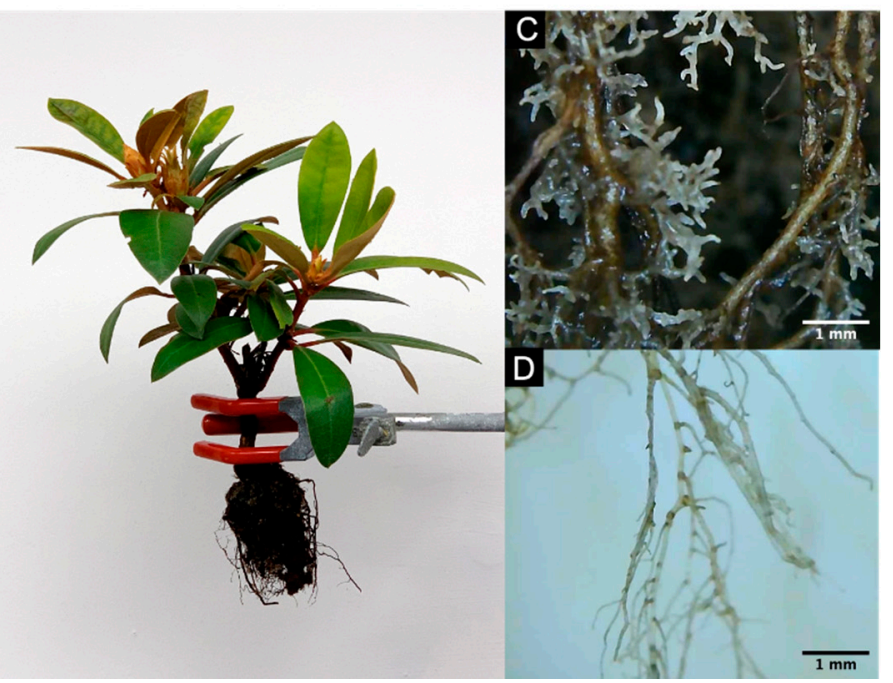

Figure 1. "Mardi Grass" rhododendron (Rhododendron spp.) after 49 days of growth in nutrient solution at pH 5.5 (A) or pH 6.5 (B). Plants developed clusters of short, highly-branched first and second order roots at $\mathrm{pH} 6.5(\mathrm{C})$, but not at $\mathrm{pH} 5.5(\mathrm{D})$.

\subsection{Nutrient Uptake and Content}

Weekly nutrient uptake was measured twice (during weeks 3 and 5 of the treatment period). To account for size differences, uptake was divided by whole plant fresh weight. N, P, and Mg uptake were not affected by nutrient solution $\mathrm{pH}$ (Figure 2). Plants took up more $\mathrm{Ca}$ (week 5), $\mathrm{Fe}, \mathrm{Cu}$, and $\mathrm{Zn}$ (week 3) when grown in high $\mathrm{pH}$ nutrient solutions than when grown in optimum $\mathrm{pH}$ solutions. Nutrient solution $\mathrm{pH}$ did not affect ferric chelate reductase activity 16 and 47 days after the start of treatments ( $p>0.136$ in all cases). Nitrate reductase activity was not affected by nutrient solution $\mathrm{pH}$ on day $28(p=0.087)$. Acid phosphatase activity was not affected by nutrient solution $\mathrm{pH}$ on day 22 $(p=0.663)$. Both of these enzymes exhibited higher activity in plants grown at $\mathrm{pH} 6.5$ than in plants grown at pH 5.5 on day 48 ( $p<0.049$ in all cases). Enzymatic activity averages can be found in Table S1.
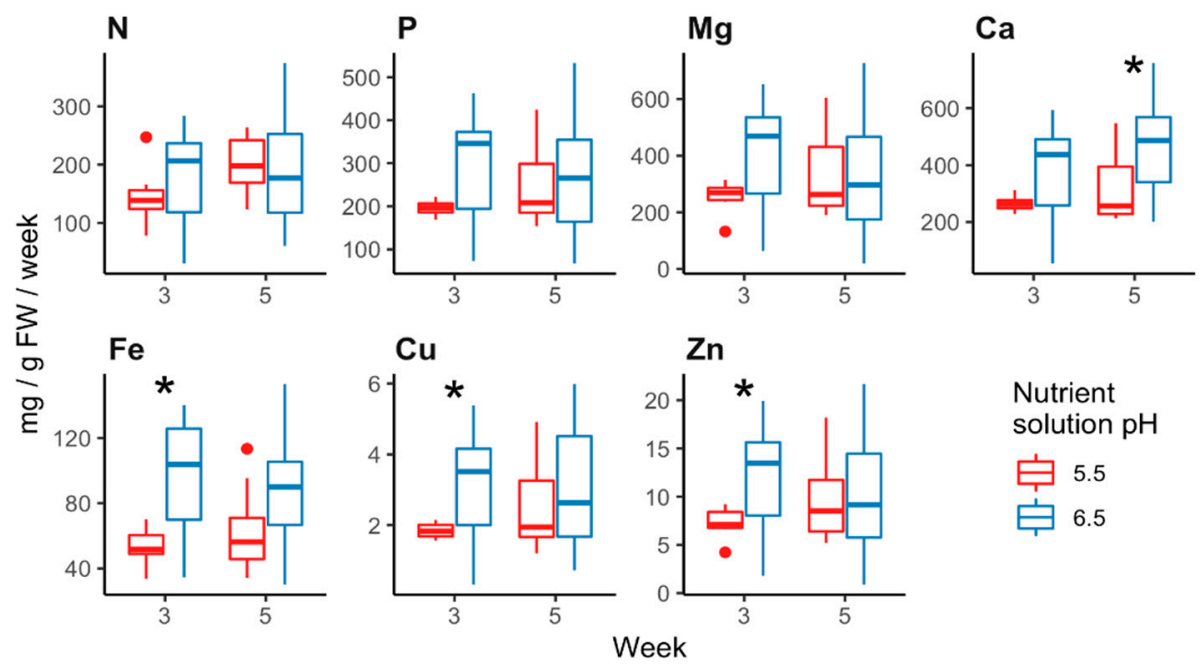

Figure 2. Weekly nutrient uptake by "Mardi Gras" rhododendron grown in nutrient solution at pH 5.5 or $\mathrm{pH}$ 6.5. Element depletion from the nutrient solution was divided by plant fresh weight to account for size differences. Asterisks indicate significant differences at $\alpha=0.05$. Dots indicate outliers.

Nutrient solution $\mathrm{pH}$ affected macro and micronutrient concentrations in roots and leaves (Table 2). Roots of plants grown in high $\mathrm{pH}$ solutions had lower $\mathrm{N}, \mathrm{S}, \mathrm{Cu}$, and $\mathrm{Zn}$ concentrations and higher Fe and $\mathrm{B}$ concentrations than roots of plants grown in optimum $\mathrm{pH}$ solutions. Leaves of plants grown 
in high $\mathrm{pH}$ solutions had lower $\mathrm{P}, \mathrm{Mg}, \mathrm{S}, \mathrm{Mn}$, and $\mathrm{B}$ concentrations and higher $\mathrm{N}$ concentrations than leaves of plants grown in optimum $\mathrm{pH}$ solutions. High $\mathrm{pH}$ solutions had the same effect in $\mathrm{S}$ concentrations in leaves and roots but contrasting effects in all other nutrient concentrations. Leaf and root Ca concentrations were not affected.

Table 2. Nutritional element concentration in roots and leaves of "Mardi Gras" rhododendron grown hydroponically in optimum ( $\mathrm{pH}$ 5.5) and high $\mathrm{pH}$ ( $\mathrm{pH}$ 6.5) nutrient solutions.

\begin{tabular}{|c|c|c|c|c|c|c|c|c|c|c|c|}
\hline \multirow{2}{*}{ Organ } & \multirow{2}{*}{$\begin{array}{c}\text { Nutrient } \\
\text { Solution } \mathrm{pH}\end{array}$} & \multicolumn{5}{|c|}{ Macronutrient Concentration (\%) } & \multicolumn{5}{|c|}{ Micronutrient Concentration (ppm) } \\
\hline & & $\mathbf{N}$ & $\mathbf{P}$ & $\mathrm{Ca}$ & Mg & S & Fe & $\mathrm{Cu}$ & Mn & Zn & B \\
\hline \multirow{3}{*}{ Roots } & 5.5 & 1.29 & 0.31 & 0.48 & 0.22 & 0.22 & 3439.90 & 57.40 & 881.80 & 162.70 & 16.50 \\
\hline & 6.5 & 0.98 & 0.35 & 0.56 & 0.24 & 0.18 & 3953.30 & 16.36 & 742.82 & 29.91 & 23.76 \\
\hline & $p$-value ${ }^{1}$ & 0.022 & 0.627 & 0.262 & 0.405 & 0.002 & 0.026 & $<0.001$ & 0.315 & $<0.001$ & $<0.001$ \\
\hline \multirow{3}{*}{ Leaves } & 5.5 & 0.83 & 0.18 & 0.47 & 0.24 & 0.28 & 47.80 & 3.10 & 179.60 & 24.30 & 31.60 \\
\hline & 6.5 & 0.94 & 0.14 & 0.45 & 0.20 & 0.23 & 50.09 & 3.45 & 103.00 & 24.00 & 26.09 \\
\hline & $p$-value ${ }^{1}$ & 0.002 & 0.002 & 0.196 & 0.025 & 0.002 & 0.687 & 0.304 & $<0.001$ & 0.896 & 0.002 \\
\hline
\end{tabular}

${ }^{1}$ Data were analyzed through one-way analysis of variance.

Nutrient solution pH also affected organ nutrient content (Table 3). Roots of plants grown in high $\mathrm{pH}$ solutions contained less $\mathrm{N}, \mathrm{S}, \mathrm{Cu}, \mathrm{Mn}$, and $\mathrm{Zn}$ than roots of plants grown in optimum $\mathrm{pH}$ solutions. Leaves of plants grown in high $\mathrm{pH}$ solutions contained less $\mathrm{Mg}$, $\mathrm{S}$, and $\mathrm{Mn}$ than leaves of plants grown in optimum $\mathrm{pH}$ solutions. Leaf and root $\mathrm{P}, \mathrm{Ca}, \mathrm{Fe}$, and $\mathrm{B}$ contents were not affected by nutrient solution $\mathrm{pH}$.

Table 3. Nutritional element content in roots and leaves of "Mardi Gras" rhododendron grown hydroponically in optimum ( $\mathrm{pH}$ 5.5) and high $\mathrm{pH}(\mathrm{pH}$ 6.5) nutrient solutions.

\begin{tabular}{|c|c|c|c|c|c|c|c|c|c|c|c|}
\hline \multirow{2}{*}{ Organ } & \multirow{2}{*}{$\begin{array}{c}\text { Nutrient } \\
\text { Solution } \mathrm{pH}\end{array}$} & \multicolumn{5}{|c|}{ Macronutrient Content (g) } & \multicolumn{5}{|c|}{ Micronutrient Content (mg) } \\
\hline & & $\mathbf{N}$ & $\mathbf{P}$ & $\mathrm{Ca}$ & Mg & $\mathbf{S}$ & $\mathrm{Fe}$ & $\mathrm{Cu}$ & Mn & $\mathrm{Zn}$ & B \\
\hline \multirow{3}{*}{ Roots } & 5.5 & 0.137 & 0.033 & 0.052 & 0.024 & 0.024 & 3.611 & 0.060 & 0.910 & 0.169 & 0.017 \\
\hline & 6.5 & 0.079 & 0.027 & 0.046 & 0.018 & 0.014 & 3.364 & 0.014 & 0.601 & 0.025 & 0.018 \\
\hline & $p$-value ${ }^{1}$ & $<0.001$ & 0.149 & 0.470 & 0.077 & $<0.001$ & 0.596 & $<0.001$ & 0.007 & $<0.001$ & 0.688 \\
\hline \multirow{3}{*}{ Leaves } & 5.5 & 0.0439 & 0.009 & 0.022 & 0.010 & 0.012 & 0.022 & 0.001 & 0.075 & 0.011 & 0.014 \\
\hline & 6.5 & 0.041 & 0.006 & 0.020 & 0.007 & 0.008 & 0.016 & 0.001 & 0.036 & 0.008 & 0.009 \\
\hline & $p$-value ${ }^{1}$ & 0.839 & 0.16 & 0.808 & 0.035 & 0.007 & 0.084 & 0.480 & 0.005 & 0.185 & 0.065 \\
\hline
\end{tabular}

${ }^{1}$ Data were analyzed through one-way analysis of variance.

\subsection{Root Stress}

Nutrient solution $\mathrm{pH}$ did not affect root membrane integrity or oxidative status consistently, as effects observed in one sampling date were absent in another date (Figure S1). Roots of plants grown in high $\mathrm{pH}$ solutions exhibited more electrolyte leakage than roots of plants grown in optimum pH solutions 21 days after the start of the experiment $(20.97 \%$ vs. $33.55 \%, p=0.002)$. Roots of plants grown in high $\mathrm{pH}$ solutions exhibited higher catalase activity than roots of plants grown in optimum $\mathrm{pH}$ solutions 19 days after the start of the experiment $\left(0.13 \mathrm{mmol} \mathrm{H}_{2} \mathrm{O}_{2} \mathrm{mg}^{-1}\right.$ fresh weight $(\mathrm{FW}) \mathrm{min}^{-1}$ vs. $0.23 \mathrm{H}_{2} \mathrm{O}_{2} \mathrm{mg}^{-1} \mathrm{FW} \mathrm{m^{-1 }}, p=0.039$ ). Electrolyte leakage on day 49 and catalase activity on day 4 were not significantly affected. Lipid peroxidation and proline concentration were not affected by nutrient solution $\mathrm{pH}$ in any of the dates tested.

\section{Discussion}

While the negative effects of growth in high $\mathrm{pH}$ soils are widely documented in rhododendron and other calcifuge plants, very little is known about the mechanism that causes these symptoms. Previously, rhododendron responses to high $\mathrm{pH}$ have been studied using $\mathrm{CaCO}_{3}$ amendments in soils 
or substrates [2,15], but carbonates elicit both $\mathrm{pH}$-dependent and $\mathrm{pH}$-independent responses [16-18]. Thus, in the present experiment, we used hydroponic solutions where $\mathrm{pH}$ can be adjusted without carbonates to study the rhododendron response to high $\mathrm{pH}$.

Rhododendron in high $\mathrm{pH}$ nutrient solutions grew less than rhododendron in optimum $\mathrm{pH}$ solutions in this experiment. These results are consistent with previous findings in rhododendron $[2,3]$ and other calcifuge plants $[8,10,14]$, and they imply the existence of one or more factors that limit growth. Our results suggest that root morphology and function might be the limiting factors. Rhododendrons grown in high $\mathrm{pH}$ nutrient solutions exhibited smaller root systems than plants grown in optimum $\mathrm{pH}$ at the end of the experiment. Even though root to shoot ratios were not affected by nutrient solution $\mathrm{pH}$ here and elsewhere [19], small root systems appear central to the high $\mathrm{pH}$ stress response because (1) high pH soils or nutrient solutions have direct contact with roots, and (2) root symptoms were more drastic than symptoms in other organs. Previous research has shown that small root systems have limited ability to access [11] or take up [20] water and nutrients in the soil. Therefore, small root systems could be a reason for the nutrient deficiencies and diminished shoot growth observed in this experiment.

High $\mathrm{pH}$ stress—or nutritional deficiencies caused by high $\mathrm{pH}$ stress—also led to the development of abnormal root system morphology. While plants grown in optimum $\mathrm{pH}$ nutrient solutions exhibited canonical rhododendron root morphology [21], plants grown in high $\mathrm{pH}$ solutions developed clusters of short, highly branched roots that resemble stress-adaptive root morphology in other plant species (e.g., proteoid roots in the family Proteaceae, cluster roots in the family Casuarinaceae, Mimosaceae, Fabaceae, Myricaceae, and Moraceae) [22]. High pH nutrient solutions increased root branching in cranberry, but it is unclear if the morphology documented by Finn et al. [14] matches our observations. Unfortunately, the imaging methods used in this experiment were not suitable for quantitative analysis of root morphology. To the best of our knowledge, this is the first report of root clusters (following the nomenclature of Lamont [20]) in the family Ericaceae. Proteoid and cluster roots have high surface area-to-mass ratios which enhance their exudation, nutrient solubilization, and nutrient uptake [23]. For example, proteoid roots are capable of acidifying the rhizosphere through $\mathrm{H}^{+}$[24] or organic acid [25] extrusion. Similar acidification capacity would enable rhododendrons to create a more favorable rhizosphere microenvironment by avoiding high $\mathrm{pH}$ stress. Rhizosphere acidification has been previously observed in rhododendron [3] and other calcifuge plants [6,26], but root morphology was not studied simultaneously. Further research should study this abnormal root morphology through quantitative methods and explore the connection between rhizosphere acidification and root clusters in rhododendron.

Another possibility is that root clusters might be a nutrient deficiency response. Other species develop proteoid or cluster roots when plant growth is limited by N, P, or Fe [23]. Leaf $\mathrm{N}$ and Fe concentrations were not affected by nutrient solution $\mathrm{pH}$ in this experiment. On the other hand, plants grown in high $\mathrm{pH}$ solutions exhibited lower leaf $\mathrm{P}$ concentrations than plants grown in optimum $\mathrm{pH}$ solutions. $\mathrm{P}$ limitations have been previously documented in blueberry [7] and other calcifuge species [10] grown in high $\mathrm{pH}$ soils. Hence, root cluster development could be related to $\mathrm{P}$ deficiency. At root level, $\mathrm{P}$ content and $\mathrm{P}$ concentration were not different between plants grown at high $\mathrm{pH}$ and plants grown at optimum $\mathrm{pH}$, suggesting root clusters might play a role in $\mathrm{P}$ uptake. Other responses to $\mathrm{P}$ deficiency, such as high acid phosphatase activity and leaf reddening were not observed. Since root sampling for acid phosphatase activity assays did not discriminate between root types (cluster vs. non-cluster), these measurements are not informative about cluster root function in this experiment. Considering differences between proteoid and non-proteoid [22] and cluster and non-cluster roots [27] have been extensively documented in other species, further research with rhododendron roots is warranted.

Other nutritional deficiencies were also observed. Leaf S and Mn concentrations and contents were lower in plants grown in high $\mathrm{pH}$ nutrient solutions than in plants grown in optimum $\mathrm{pH}$ solutions. Root $\mathrm{S}$ and $\mathrm{Mn}$ content were similarly affected. Blueberry and cranberry also exhibited 
lower shoot Mn concentrations in high $\mathrm{pH}$ soils solutions than in low $\mathrm{pH}$ ones [8]. Considering that biomass accumulation, nutrient concentration, and nutrient content were negatively impacted, it is possible that $S$ and/or Mn deficiency were limiting to growth [28]. Other results were less intuitive and must be considered in the context of the different growth rates in each treatment. Some elements were deficient in leaves but not in roots $(\mathrm{Mg})$, others deficient in roots but not in leaves $(\mathrm{N}, \mathrm{Cu}, \mathrm{Zn})$, and others exhibited differences in nutrient concentration but not in nutrient content (B). Since plants grown in optimum $\mathrm{pH}$ nutrient solutions were larger than plants grown in high $\mathrm{pH}$ nutrient solutions at the end of the experiment, leaf nutrient concentrations in the former group could have suffered a "dilution effect". This effect could explain leaf concentration trends, particularly for $\mathrm{N}$ which is mobile within the plant [29]. These results underscore the complex, widespread impact high $\mathrm{pH}$ has in nutrient uptake and translocation by rhododendron.

In this experiment, plants grown in high $\mathrm{pH}$ nutrient solutions were not Fe deficient and they did not develop chlorosis. Fe deficiency is commonly observed in plants grown in high $\mathrm{pH}$ soils [8], because Fe is less bioavailable under these conditions [30]. Chlorosis is an Fe deficiency symptom that has been used to identify rhododendrons that can tolerate high $\mathrm{pH}$ soils [3-5,15]. It is possible that deficiency was avoided because stressed plants grew very slowly, Fe was delivered as a pH-stable chelate in the nutrient solution, or the treatment period was short. Nevertheless, our results suggest that chlorosis might not be an informative phenotype to select rhododendrons that tolerate high $\mathrm{pH}$, because high $\mathrm{pH}$ stress caused numerous stress responses in absence of this leaf symptom.

Nutrient solution $\mathrm{pH}$ might have also affected nutrient bioavailability and translocation. Root Fe concentrations were higher in rhododendrons grown in high $\mathrm{pH}$ nutrient solutions than in rhododendrons grown in low $\mathrm{pH}$ solutions, but leaf concentration was not affected. This suggests that $\mathrm{Fe}$ in the roots was either not bioavailable or that translocation was impaired. While high $\mathrm{Fe}$ concentrations in roots could be caused by higher Fe uptake at $\mathrm{pH}$ 6.5, unaffected ferric chelate reductase activity rates suggest some of this Fe was likely unavailable to the plant. Rhododendron and several other plants have total and "active" Fe pools [15,31]. The former includes all the Fe present in an organ, while the latter includes only the bioavailable fraction. Fe precipitation is strongly $\mathrm{pH}$ dependent [30]. Thus, high $\mathrm{pH}$ nutrient solutions could have caused apoplastic Fe precipitation, making Fe unavailable to the plant. The analytical methods used here could not distinguish active and total Fe pools.

Root $\mathrm{B}$ concentration was higher in rhododendrons grown in high $\mathrm{pH}$ nutrient solutions than in rhododendrons grown in low $\mathrm{pH}$ solutions. In agreement with previous research in blueberry [7], leaf $\mathrm{B}$ concentrations were lower in plants grown in high $\mathrm{pH}$ solutions than in plants grown in optimum $\mathrm{pH}$ solutions. This pattern suggests that plants are either accumulating $B$ in the roots or translocating $B$ from the shoots to roots. B retranslocation is species-dependent [32]. Thus, additional research will be necessary to determine if rhododendron can translocate $B$ to the roots, leading to the observed pattern.

Unlike with other species [33-35], high $\mathrm{pH}$ nutrient solution led to a nuanced oxidative stress response in rhododendron. Oxidative status depends on the balance between reactive oxygen species (ROS) and antioxidants in plant cells. Previous research has shown that high $\mathrm{pH}$ can disrupt this balance by promoting ROS production [35] and limiting the availability of the micronutrient cofactors required by antioxidant enzymes [36,37]. Here, high $\mathrm{pH}$ nutrient solutions increased Fe concentration but decreased $\mathrm{Cu}$ and $\mathrm{Zn}$ concentrations in the roots. Fe excess can lead to ROS production through Fenton reactions [38]. Nevertheless, rhododendron grown in high $\mathrm{pH}$ nutrient solutions did not exhibit increased lipid peroxidation-a common assessment of oxidative stress. In agreement with this, enzymatic (catalase) and non-enzymatic (proline) antioxidants were generally not affected by nutrient solution $\mathrm{pH}$. Considering the sparse sampling for oxidative status in this experiment, future research should expand on these observations.

In conclusion, high $\mathrm{pH}$ nutrient solutions cause widespread stress symptoms in rhododendron. Plants grown in high $\mathrm{pH}$ solutions exhibited diminished growth, abnormal root morphology, and impaired root function. Concentration, content, and uptake of most nutritional elements were 
affected by high $\mathrm{pH}$ solutions. S and Mn deficiencies likely limited plant growth. Altogether, these results indicate that high $\mathrm{pH}$ stress directly impacts roots and, through the resulting nutrient deficiencies, indirectly affects the rest of the plant.

\section{Materials and Methods}

\subsection{Plant Material and Cultivation}

One-year-old liners (average FW $36.70 \pm 1.90 \mathrm{~g}$ ) of "Mardi Gras" rhododendron (Rhododendron yakushimanum ssp. yakushimanum "Koichiro Wada" $\times$ Rhododendron griersonianum "Vanessa") were acquired from a commercial nursery. Roots were washed clean of substrate using tap water. Then, plants were transplanted to 2.0-L bottles filled with a continuously-aerated nutrient solution as per Darnell and Cruz Huerta [39]. The nutrient solution contained $0.5 \mathrm{mM} \mathrm{KNO}_{3}, 0.5 \mathrm{mM} \mathrm{K}_{2} \mathrm{HPO}_{4}, 1.0 \mathrm{mM}$ $\mathrm{MgSO}_{4}, 0.5 \mathrm{mM} \mathrm{CaCl}_{2}, 45 \mu \mathrm{M} \mathrm{H}_{3} \mathrm{BO}_{3}, 45 \mu \mathrm{M} \mathrm{Fe}$ (delivered as Sequestrene 330 ${ }^{\mathrm{TM}}$ (Becker Underwood, Inc.)), $10 \mu \mathrm{M} \mathrm{MnSO}_{4}, 10 \mu \mathrm{M} \mathrm{ZnSO}_{4}, 0.3 \mu \mathrm{M} \mathrm{CuSO}_{4}$, and $0.2 \mu \mathrm{M} \mathrm{Na}_{2} \mathrm{MoO}_{4}$. The nutrient solution was buffered using $5.0 \mathrm{mM}$ 2-(N-morpholino) ethanesulfonic acid (MES). Nutrient solutions were changed on a weekly basis to maintain concentrations nearly constant. When necessary, deionized water was added to the bottles to compensate for water loss due to evapotranspiration.

Plants were acclimated to the hydroponic system for 22 days. During this period, nutrient solution was maintained at $\mathrm{pH}$ 5.5. Subsequently, plants were weighed and randomly assigned to one of two treatment groups. Half of the plants remained in nutrient solution at $\mathrm{pH} 5.5$, while the other half were transferred to nutrient solutions at $\mathrm{pH}$ 6.5. Nutrient solution $\mathrm{pH}$ was adjusted using $\mathrm{KOH}$ or $\mathrm{HCl}$ as necessary. The treatment period lasted 49 days. A timeline detailing the timing of data collection can be found in Figure S2.

The experiment was conducted in a walk-in growth chamber equipped with LED lights (K5 series model XL750, Kind Lights, Santa Rosa, CA) delivering an average photosynthetic photon flux of $278 \mu \mathrm{mol} \mathrm{m}{ }^{-2} \mathrm{~s}^{-1}$. Average temperature was $22.29{ }^{\circ} \mathrm{C}$ and average relative humidity was $70.98 \%$ during the experiment.

\subsection{Enzymatic Measurements}

Activity of the rate-limiting enzymes for $\mathrm{NO}_{3}{ }^{-}, \mathrm{Fe}$, and $\mathrm{P}$ uptake was measured on root samples collected during the treatment period. These enzyme measurements have been used to characterize nutrient uptake responses in calcifuge plants [39-41].

Nitrate reductase activity was measured as per Darnell and Cruz-Huerta [39] with modifications. Approximately, $40 \mathrm{mg}$ of root tips was collected in tubes containing $0.2 \mathrm{mM} \mathrm{CaSO}_{4}$ on ice. Two root samples per plant were placed in tubes containing an assay solution composed of $100 \mathrm{mM} \mathrm{KH}_{2} \mathrm{PO}_{4}$ at $\mathrm{pH} 7.5,30 \mathrm{mM} \mathrm{KNO} 3$ and $2 \% \mathrm{v} / \mathrm{v}$ 1-propanol. Roots were removed from one sample per plant and used to assess root $\mathrm{NO}_{2}{ }^{-}$concentration at the start of the assay. The second root sample from each plant was incubated under continuous shaking ( $540 \mathrm{rpm}$ ) for $60 \mathrm{~min}$ at $31^{\circ} \mathrm{C}$ in the dark. Then, $150 \mu \mathrm{L}$ of assay solution was mixed with $150 \mu \mathrm{L}$ sulfanilamide $(1 \% \mathrm{w} / \mathrm{v}$ in $1.5 \mathrm{~N} \mathrm{HCl})$ and $150 \mu \mathrm{L}$ $\mathrm{N}$-(1-naphthyl)-ethylenediamine dihydrochloride $(0.02 \% \mathrm{w} / \mathrm{v}$ in $0.2 \mathrm{~N} \mathrm{HCl})$ and incubated again at $22{ }^{\circ} \mathrm{C}$ for $30 \mathrm{~min}$ in the dark. Finally, absorbance $(540 \mathrm{~nm})$ of the reacted solution was measured using a microplate reader (Synergy HT, BioTek Instruments, Winooski, VT, USA). $\mathrm{NO}_{2}{ }^{-}$concentration was quantified using a standard curve prepared with $\mathrm{KNO}_{2}$. Nitrate reductase activity was measured 28 and 48 days after the start of the treatment period.

Ferric chelate reductase activity was measured as per Nunez et al. [42]. Root samples were collected as described above. Root samples were blotted dry and transferred to an assay solution containing $0.2 \mathrm{mM} \mathrm{CaSO}_{4}, 5.0 \mathrm{mM}$ MES at pH 5.5, $0.1 \mathrm{mM}$ ethylenediaminetetraacetic acid iron (III) sodium salt, and $0.2 \mathrm{mM}$ bathophenanthroline disulfonic acid disodium salt hydrate. Roots were incubated under continuous shaking ( $540 \mathrm{rpm}$ ) for $60 \mathrm{~min}$ at $22{ }^{\circ} \mathrm{C}$ in the dark. After incubation, absorbance ( $535 \mathrm{~nm}$ ) of assay solution aliquots was measured using a microplate reader. $\mathrm{Fe}^{2+}$ concentration was computed 
using a molar extinction coefficient of $2.2 \times 10^{4} \mathrm{M}^{-1} \mathrm{~cm}^{-1}$ [43]. Assay solution samples incubated without roots and without Fe were used as controls. Ferric chelate reductase activity was measured 16 and 47 days after the start of the treatment period.

Acid phosphatase activity was measured as per Tabatai and Bremner [44]. Root tip samples were collected in tubes containing $50 \mathrm{mM}$ sodium acetate at $\mathrm{pH} 5.5$ on ice. Following, samples were blotted dry and transferred to an assay solution containing $50 \mathrm{mM}$ sodium acetate at pH 5.5 and $270 \mathrm{mM}$ p-nitrophenol. Roots were incubated under continuous shaking (540 rpm) for $30 \mathrm{~min}$ at $30{ }^{\circ} \mathrm{C}$ in the dark as per Zhang et al. [45]. After incubation, phosphatase activity was inhibited by adding $0.50 \mathrm{M} \mathrm{NaOH}$ and vortexing. Absorbance $(405 \mathrm{~nm})$ of inhibited solution was measured using a microplate reader. p-nitrophenol concentration was computed using a molar extinction coefficient of $1.83 \times 10^{4} \mathrm{M}^{-1} \mathrm{~cm}^{-1}$. Acid phosphatase activity was measured 22 and 44 days after the start of the treatment period.

\subsection{Stress Response Measurements}

Membrane integrity was assessed through the electrolyte leakage method as per McKay and White et al. [46]. Root samples were collected in aliquots of the nutrient solution in which they were growing. Then, roots were blotted and weighed before incubation in $16 \mathrm{~mL}$ deionized $\mathrm{H}_{2} \mathrm{O}$. After $24 \mathrm{~h}$ of incubation under continuous shaking (130 rpm), assay solution electrical conductivity was measured with a standardized meter (model XL30, Fisher Scientific Inc., Waltham, MA, USA). Then, roots and assay solution were autoclaved for $60 \mathrm{~min}$ at $121^{\circ} \mathrm{C}$ and electrical conductivity was measured again. Control tubes containing no roots were incubated and measured identically. Relative electrolyte leakage was expressed as a percentage of total electrolytes extracted during the incubation period. Membrane integrity was measured 21 and 49 days after the start of the treatment period.

Root tip samples for lipid peroxidation, catalase activity, and proline concentration measurements were flash frozen using liquid $\mathrm{N}$ and stored at $-80^{\circ} \mathrm{C}$ until processing. Samples were collected twice during the experiment to minimize root injury. Approximately, $40 \mathrm{mg}$ of frozen root tips were used to measure lipid peroxidation using the malondialdehyde method as per Shen et al. [47]. Root tissue was disrupted in tubes containing $1 \mathrm{~mL}$ of $5 \%$ trichloroacetic acid and two $3 \mathrm{~mm}$ metal beads at a frequency of $1 / 30 \mathrm{~Hz}$ for $90 \mathrm{~s}$ (TissueLyser II, QIAgen GmbH, Hilden, Germany). Samples were centrifuged at $12,000 \times \mathrm{g}$ for $20 \mathrm{~min}$ at $4{ }^{\circ} \mathrm{C}$. Supernatant was collected and split into three $200 \mathrm{uL}$ aliquots. Samples were reacted with $200 \mu \mathrm{L} 0.67 \%$ thiobarbituric acid at $99^{\circ} \mathrm{C}$ for $30 \mathrm{~min}$. Tubes were placed on ice to halt the reaction, and then centrifuged at $10,000 \times g$ for $10 \mathrm{~min}$ at $4{ }^{\circ} \mathrm{C}$. Absorbance $(532 \mathrm{~nm}$ and $600 \mathrm{~nm}$ ) of the supernatant was measured in a microplate reader. Control tubes containing no roots were incubated and measured identically. Malondialdehyde concentration was calculated using molar extinction coefficient $155 \mathrm{mM}^{-1} \mathrm{~cm}^{-1}$. Lipid peroxidation was measured 19 and 33 days after the start of the treatment period.

Approximately $100 \mathrm{mg}$ of frozen root tips was used to measure catalase activity. Roots were disrupted as detailed above in tubes containing $600 \mu \mathrm{L}$ extraction solution containing $0.20 \mathrm{M}$ potassium phosphate buffer ( $\mathrm{pH} 7.0$ ) and $0.1 \mathrm{mM}$ ethylenediaminetetraacetic acid. Samples were then centrifuged at $15,000 \times \mathrm{g}$ for $20 \mathrm{~min}$ at $4{ }^{\circ} \mathrm{C}$. Supernatant was collected and transferred to a new tube. The process was repeated after adding $400 \mu \mathrm{L}$ of extraction solution and centrifuging at 15,000 $\mathrm{g}$ for $15 \mathrm{~min}$ at $4{ }^{\circ} \mathrm{C}$. Supernatant from both extractions was pooled and diluted to $75 \%$ with $50 \mathrm{mM}$ potassium phosphate buffer at $\mathrm{pH} 7.0$ (dilution solution). Catalase activity was measured as $\mathrm{H}_{2} \mathrm{O}_{2}$ detoxification using the pertitanic acid method as per Hadwan and Khabt [48]. In triplicate reactions, $25 \mu \mathrm{L}$ of dilute supernatant was mixed with $250 \mu \mathrm{L}$ of peroxide solution $(30 \mathrm{mM}$ hydrogen peroxide in dilution solution) and incubated for $3 \mathrm{~min}$ at $37^{\circ} \mathrm{C}$. Then, the reaction was stopped by adding $750 \mu \mathrm{L}$ of development solution $\left(0.1 \% \mathrm{TiCl}_{4}\right.$ in $\left.20 \% \mathrm{H}_{2} \mathrm{SO}_{4}\right)$. Absorbance $(405 \mathrm{~nm})$ of the developed solution was measured in a microplate reader. Control tubes containing no supernatant and no peroxide were incubated and measured identically. $\mathrm{H}_{2} \mathrm{TiO}_{4}$ concentration was calculated using molar extinction coefficient $689 \mathrm{M}^{-1} \mathrm{~cm}^{-1}$. Catalase activity was measured 4 and 19 days after the start of the treatment 
period. Five reactions exhibited negative values on each sampling date. Negative values were removed from the analysis, leading to $\mathrm{n}<10$ and uneven sample size between treatments.

Approximately $40 \mathrm{mg}$ of frozen root tips were used to measure proline concentration using the ninhydrin method as per Bates et al. [49]. Acidic ninhydrin stock was prepared within $24 \mathrm{~h}$ of the assay using $1.25 \mathrm{~g}$ of ninhydrin stored under inert gas, $30 \mathrm{~mL}$ of glacial acetic acid, and $20 \mathrm{~mL}$ of $6 \mathrm{M}$ orthophosphoric acid. Roots were disrupted, as detailed above, in tubes containing $3 \%$ sulfosalicylic acid. Disrupted samples were centrifuged at $16,000 \times g$ for $5 \mathrm{~min}$ at room temperature. Then, $100 \mu \mathrm{L}$ of supernatant was mixed with $100 \mu \mathrm{L}$ of $3 \%$ sulfosalicylic acid, $200 \mu \mathrm{L}$ of acidic ninhydrin stock, and $200 \mu \mathrm{L}$ of glacial acetic acid. Tubes were vortexed and incubated at $96{ }^{\circ} \mathrm{C}$ for $60 \mathrm{~min}$. The reaction was terminated by placing tubes on ice. The chromogen was collected with $500 \mu \mathrm{L}$ of toluene in a $5 \mathrm{~min}$ incubation at room temperature. Absorbance $(520 \mathrm{~nm})$ of the toluene fraction was measured in a microplate reader. Proline concentration was calculated using a standard curve. Proline concentration was measured 19 and 33 days after the start of the treatment period.

\subsection{Nutrient Uptake}

Nutrient uptake was measured as element depletion from nutrient solutions as per Nunez et al. [31]. Plants received $2 \mathrm{~L}$ of nutrient solution at the start of each week. Nutrient solution volume was measured after 7 days of hydroponic cultivation. Nutrient solution samples were collected at the start and end of the week. Samples were acidified with 1 drop of $12 \mathrm{M} \mathrm{HCl}$ and submitted to an institutional laboratory (University of Florida Institute of Food and Agricultural Sciences Analytical Research Laboratory, Gainesville, FL) for elemental analysis by inductively coupled plasma-atomic emission spectrometry [50]. Nutrient content at the start and end of the week were computed by multiplying nutrient solution volume and concentration. Differences in nutrient content between the start and end of the week were assumed to reflect plant nutrient uptake.

\subsection{Destructive Harvest}

Plants were destructively harvested at the end of the treatment period. Whole plant and organ by organ fresh weight (FW) were measured after blotting root systems dry. Then, relative growth rate was calculated as the difference between the natural logarithm of the fresh weight at the start and the end of the treatment period [51]. Leaf chlorosis was assessed using two different greenness meters: one based on light transmittance (SPAD 502, Konika Minolta, Osaka, Japan) and one based on image analysis (FieldScout Green Index+, Spectrum Technologies Inc., Aurora, IL, USA). Leaves were laid flat on a white background and photographed using a mobile phone camera (iPhone X, Apple Inc., Cupertino, CA, USA) placed $48 \mathrm{~cm}$ away. Then, total leaf area was measured using ImageJ version 1.51 [52]. Roots were observed and photographed with a digital microscope (Q-Scope 13200 Lite, Euromex Microscopen B.V., Arnhem, The Netherlands). Following, the tissue was dried to a constant weight at $72{ }^{\circ} \mathrm{C}$, ground until it passed through a size- 20 mesh and submitted for elemental analysis at a commercial laboratory (Waters Laboratory, Camila, GA, USA).

\subsection{Data Analysis}

The experiment followed a completely randomized design with one treatment (nutrient solution $\mathrm{pH}$ ) and two levels (pH5.5 and pH 6.5). There were 10 single-plant replications per treatment. Data were analyzed through one-way ANOVA using package agricolae [53] in R (version 3.6.2; R Foundation for Statistical Computing, Vienna, Austria). Where the sample size was uneven, treatments were compared though one-way ANOVA using the type III sum of squares with the car package [54]. Data were illustrated using package ggplot2 [55].

Supplementary Materials: The following are available online at http:/www.mdpi.com/2223-7747/9/8/1019/s1, Figure S1: Root stress measurements in 'Mardi Gras' rhododendron, Figure S2: Timeline of data collection, Table S1: Activity rates of enzymes involved in nutrient uptake. 
Author Contributions: Conceptualization, G.H.N.; methodology, data collection, and analysis A.J.T., C.I.A., and G.H.N.; writing-original draft preparation, A.J.T. and C.I.A.; writing-review and editing, G.H.N.; funding acquisition, G.H.N., A.J.T., and C.I.A. All authors have read and agreed to the published version of the manuscript.

Funding: This research was funded by the Research Foundation of the American Rhododendron Society. A.J.T. was funded by a Summer Undergraduate Research Fellowship from the American Society of Plant Biologists. C.I.A. was funded by the University of Florida College of Agricultural and Life Sciences University Scholars Program.

Acknowledgments: The authors greatly thank Laila Khandaker, Michael Schreiber, Marina Curtis, Giancarlo Buzzi, and Jesenia Cortes for their assistance in plant maintenance and data collection.

Conflicts of Interest: The authors declare no conflict of interest. The funders had no role in the design of the study; in the collection, analyses, or interpretation of data; in the writing of the manuscript, or in the decision to publish the results.

\section{References}

1. Wang, S.; Leus, L.; Van Labeke, M.-C.; Van Huylenbroeck, J. Prediction of lime tolerance in rhododendron based on herbarium specimen and geochemical data. Front. Plant Sci. 2018, 9, 1538. [CrossRef] [PubMed]

2. Giel, P.; Bojarczuk, K. Effects of high concentrations of calcium salts in the substrate and its $\mathrm{pH}$ on the growth of selected rhododendron cultivars. Acta Soc. Bot. Pol. 2011, 80, 105-114. [CrossRef]

3. Susko, A.Q.; Rinehart, T.A.; Bradeen, J.M.; Hokanson, S.C. An evaluation of two seedling phenotyping protocols to assess $\mathrm{pH}$ adaptability in deciduous azalea (rhododendron sect. pentanthera G. don). HortScience 2018, 53, 268-274. [CrossRef]

4. Dunemann, F.; Kahnau, R.; Stange, I. Analysis of complex leaf and flower characters in Rhododendron using a molecular linkage map. Theor. Appl. Genet. 1999, 98, 1146-1155. [CrossRef]

5. Scariot, V.; Caser, M.; Kobayashi, N. Evergreen azaleas tolerant to neutral and basic soils: Breeding potential of wild genetic resources. Acta Hort. 2013, 287-291. [CrossRef]

6. Jiang, Y.; Zeng, Q.; Wei, J.; Jiang, J.; Li, Y.; Chen, J.; Yu, H. Growth, fruit yield, photosynthetic characteristics, and leaf microelement concentration of two blueberry cultivars under different long-term soil $\mathrm{pH}$ treatments. Agronomy 2019, 9, 357. [CrossRef]

7. Finn, C.E.; Rosen, C.J.; Luby, J.J.; Ascher, P.D. Blueberry germplasm screening at several soil pH regimes. II. plant nutrient composition. J. Am. Soc. Hortic. Sci. 1993, 118, 383-387. [CrossRef]

8. Rosen, C.J.; Allan, D.L.; Luby, J.J. Nitrogen form and solution $\mathrm{pH}$ influence growth and nutrition of two vaccinium clones. J. Am. Soc. Hortic. Sci. 1990, 115, 83-89. [CrossRef]

9. Preil, W.; Ebbinghaus, R. Breeding of lime tolerant rhododendron rootstocks. Acta Hortic. 1994, 364, 61-70. [CrossRef]

10. Marrs, R.H.; Bannister, P. Response of several members of the ericaceae to soils of contrasting $\mathrm{pH}$ and base-status. J. Ecol. 1978, 66, 829-834. [CrossRef]

11. Wijesinghe, D.K.; John, E.A.; Beurskens, S.; Hutchings, M.J. Root system size and precision in nutrient foraging: Responses to spatial pattern of nutrient supply in six herbaceous species. J. Ecol. 2001, 89, 972-983. [CrossRef]

12. Payá-Milans, M.; Nunez, G.H.; Olmstead, J.W.; Rinehart, T.A.; Staton, M. Regulation of gene expression in roots of the $\mathrm{pH}$-sensitive Vaccinium corymbosum and the $\mathrm{pH}$-tolerant Vaccinium arboreum in response to near neutral pH stress using RNA-Seq. BMC Genom. 2017, 18, 580. [CrossRef] [PubMed]

13. Allan, D.L.; Cook, B.D.; Rosen, C.J. Nitrogen form and solution pH effect on organic acid content of cranberry roots and shoots. HortScience 1994, 29, 313-315. [CrossRef]

14. Finn, C.E.; Rosen, C.J.; Luby, J.J. Nitrogen form and solution pH effects on root anatomy of cranberry. HortScience 1990, 25, 1419-1421. [CrossRef]

15. Demasi, S.; Caser, M.; Handa, T.; Kobayashi, N.; De Pascale, S.; Scariot, V. Adaptation to iron deficiency and high $\mathrm{pH}$ in evergreen azaleas (Rhododendron spp.): Potential resources for breeding. Euphytica 2017, 213, 148. [CrossRef]

16. Covarrubias, J.I.; Rombolà, A.D. Physiological and biochemical responses of the iron chlorosis tolerant grapevine rootstock 140 Ruggeri to iron deficiency and bicarbonate. Plant Soil 2013, 370, 305-315. [CrossRef]

17. Ksouri, R.; M'rah, S.; Gharsalli, M.; Lachaâl, M. Biochemical responses to true and bicarbonate-induced iron deficiency in grapevine genotypes. J. Plant Nutr. 2006, 29, 305-315. [CrossRef] 
18. Jelali, N.; Salah, I.B.; M'sehli, W.; Donnini, S.; Zocchi, G.; Gharsalli, M. Comparison of three pea cultivars (Pisum sativum) regarding their responses to direct and bicarbonate-induced iron deficiency. Sci. Hortic. 2011, 129, 548-553. [CrossRef]

19. Finn, C.E.; Luby, J.J.; Rosen, C.J.; Ascher, P.D. Blueberry germplasm screening at several soil $\mathrm{pH}$ regimes. I. Plant survival and growth. J. Am. Soc. Hortic. Sci. 1993, 118, 377-382. [CrossRef]

20. Lamont, B. Mechanisms for enhancing nutrient uptake in plants, with particular reference to mediterranean South Africa and Western Australia. Bot. Rev. 1982, 48, 597-689. [CrossRef]

21. Peterson, T.; Mueller, W.; Englander, L. Anatomy and ultrastructure of a Rhododendron root-fungus association. Can. J. Bot. 1980, 58, 2421-2433. [CrossRef]

22. Dinkelaker, B.; Hengeler, C.; Marschner, H. Distribution and function of proteoid roots and other root clusters. Bot. Acta 1995, 108, 183-200. [CrossRef]

23. Lamont, B. Structure, ecology and physiology of root clusters-A review. Plant Soil 2003, 248, 1-19. [CrossRef]

24. Grierson, P.; Attiwill, P. Chemical characteristics of the proteoid root mat of banksia integrifolia L. Aust. J. Bot. 1989, 37, 137. [CrossRef]

25. Watt, M.; Evans, J.R. Proteoid roots. Physiology and development. Plant Physiol. 1999, 121, 317-323. [CrossRef]

26. Imler, C.; Arzola, C.; Nunez, G. Ammonium uptake is the main driver of rhizosphere $\mathrm{pH}$ in southern highbush blueberry. HortScience 2019, 54, 955-959. [CrossRef]

27. Hawkins, H.J.; Wolf, G.; Stock, W.D. Cluster roots of leucadendron laureolum (proteaceae) and lupinus albus (fabaceae) take up glycine intact: An adaptive strategy to low mineral nitrogen in soils? Ann. Bot. 2005, 96, 1275-1282. [CrossRef]

28. Scagel, C.F. Growth and nutrient use of ericaceous plants grown in media amended with sphagnum moss peat or coir dust. HortScience 2003, 38, 46-54. [CrossRef]

29. Marschner, P. Mineral Nutrition of Higher Plants, 3rd ed.; Academic Press: Amsterdam, The Netherlands, 2012.

30. Lemanceau, P.; Bauer, P.; Kraemer, S.; Briat, J.-F. Iron dynamics in the rhizosphere as a case study for analyzing interactions between soils, plants and microbes. Plant Soil 2009, 321, 513-535. [CrossRef]

31. Nunez, G.H.; Olmstead, J.W.; Darnell, R.L. Rhizosphere acidification is not part of the strategy I iron deficiency response of Vaccinium arboretum and the southern highbush blueberry. HortScience 2015, 50, 1064-1069. [CrossRef]

32. Brown, P.; Shelp, B. Boron mobility in plants. Plant Soil 1997, 193, 85-101. [CrossRef]

33. Zhang, J.-T.; Mu, C.-S. Effects of saline and alkaline stresses on the germination, growth, photosynthesis, ionic balance and anti-oxidant system in an alkali-tolerant leguminous forage Lathyrus quinquenervius. Soil Sci. Plant Nutr. 2009, 55, 685-697. [CrossRef]

34. Zhang, H.; Li, X.; Guan, Y.; Li, M.; Wang, Y.; An, M.; Zhang, Y.; Liu, G.; Xu, N.; Sun, G. Physiological and proteomic responses of reactive oxygen species metabolism and antioxidant machinery in mulberry (Morus alba L.) seedling leaves to $\mathrm{NaCl}$ and $\mathrm{NaHCO} 3$ stress. Ecotoxicol. Environ. Saf. 2020, 193, 110259. [CrossRef]

35. Khan, A.; Kamran, M.; Imran, M.; Al-Harrasi, A.; Al-Rawahi, A.; Al-Amri, I.; Lee, I.-J.; Khan, A.L. Silicon and salicylic acid confer high-pH stress tolerance in tomato seedlings. Sci. Rep. 2019, 9, 19788. [CrossRef] [PubMed]

36. Valipour, M.; Baninasab, B.; Khoshgoftarmanesh, A.H.; Gholami, M. Oxidative stress and antioxidant responses to direct and bicarbonate-induced iron deficiency in two quince rootstocks. Sci. Hortic. 2020, 261, 108933. [CrossRef]

37. Iturbe-Ormaetxe, I.; Moran, J.; Arrese-Igor, C.; Gogorcena, Y.; Klucas, R.; Becana, M. Activated oxygen and antioxidant defences in iron-deficient pea plants. Plant Cell Environ. 1995, 18, 421-429. [CrossRef]

38. Becana, M.; Moran, J.; Iturbe-Ormaetxe, I. Iron-dependent oxygen free radical generation in plants subjected to environmental stress: Toxicity and antioxidant protection. Plant Soil 1998, 201, 137-147. [CrossRef]

39. Darnell, R.L.; Cruz-Huerta, N. Uptake and assimilation of nitrate and iron in cultivated and wild Vaccinium species. Int. J. Fruit Sci. 2011, 11, 136-150. [CrossRef]

40. Poonnachit, U.; Darnell, R. Effect of ammonium and nitrate on ferric chelate reductase and nitrate reductase in Vaccinium species. Ann. Bot. 2004, 93, 399-405. [CrossRef]

41. Dighton, J.; Coleman, D.C. Phosphorus relations of roots and mycorrhizas of Rhododendron maximum L. in the southern Appalachians, North Carolina. Mycorrhiza 1992, 1, 175-184. [CrossRef] 
42. Nunez, G.H.; Harmon, C.L.; Olmstead, J.W.; Darnell, R.L. Root-level inoculation with iron-reducing microorganisms does not enhance iron uptake by southern highbush blueberry plants. Rhizosphere 2016, 2, 24-33. [CrossRef]

43. Chaney, R.L.; Brown, J.C.; Tiffin, L.O. Obligatory reduction of ferric chelates in iron uptake by soybeans. Plant Physiol. 1972, 50, 208-213. [CrossRef] [PubMed]

44. Tabatabai, M.; Bremner, J. Use of p-nitrophenyl phosphate for assay of soil phosphatase activity. Soil Biol. Biochem. 1969, 1, 301-307. [CrossRef]

45. Zhang, D.; Zhang, C.; Tang, X.; Li, H.; Zhang, F.; Rengel, Z.; Whalley, W.R.; Davies, W.J.; Shen, J. Increased soil phosphorus availability induced by faba bean root exudation stimulates root growth and phosphorus uptake in neighbouring maize. N. Phytol. 2016, 209, 823-831. [CrossRef]

46. McKay, H.; White, M. Fine root electrolyte leakage and moisture content: Indices of sitka spruce and douglas-fir seedling performance after desiccation. New For. 1997, 13, 139-162. [CrossRef]

47. Shen, H.F.; Zhao, B.; Xu, J.J.; Liang, W.; Huang, W.M.; Li, H.H. Effects of heat stress on changes in physiology and anatomy in two cultivars of Rhododendron. South Afr. J. Bot. 2017, 112, 338-345. [CrossRef]

48. Hadwan, M.H.; Khabt, H. Simple spectrophotometric method for analysis of serum catalase activity. JCDR 2018. [CrossRef]

49. Bates, L.S.; Waldren, R.P.; Teare, I.D. Rapid determination of free proline for water-stress studies. Plant Soil 1973, 39, 205-207. [CrossRef]

50. U.S. Environmental Protection Agency. Determination of Trace Elements in Waters and Wastes by Inductively Coupled Plasma-Mass Spectrometry, p. 200.8-1-200.8-51; Office of Research and Development U.S. Environmental Protection Agency: Cincinnati, OH, USA, 1994.

51. Hunt, R. Plant Growth Curves: The Functional Approach to Plant Growth Analysis; Edward Arnold: London, UK, 1984.

52. Rueden, C.T.; Schindelin, J.; Hiner, M.C.; DeZonia, B.E.; Walter, A.E.; Arena, E.T.; Eliceiri, K.W. ImageJ2: ImageJ for the next generation of scientific image data. BMC Bioinform. 2017, 18, 529. [CrossRef]

53. de Mendiburu, F. Agricolae: Statistical Procedures for Agricultural Research. Available online: https: //www.cran.r-project.org/web/packages/agricolae/index.html (accessed on 18 June 2020).

54. Fox, J.; Weisberg, S. An R Companion to Applied Regression, 3rd ed.; SAGE: Thousand Oaks, CA, USA, 2019.

55. Wickham, H. Ggplot2; Springer: Dordrecht, The Netherlands, 2009.

(C) 2020 by the authors. Licensee MDPI, Basel, Switzerland. This article is an open access article distributed under the terms and conditions of the Creative Commons Attribution (CC BY) license (http://creativecommons.org/licenses/by/4.0/). 